\title{
Retrospective analysis of burn injuries caused by hot milk in 159 pediatric patients: 14 years of experience in a burn unit
}

\author{
Yalcin Yontar, M.D., ${ }^{1}$ Aliye Esmaoglu, M.D., ${ }^{2}$ Atilla Coruh, M.D. ${ }^{1}$ \\ ${ }^{1}$ Department of Plastic, Reconstructive and Aesthetic Surgery, Erciyes University Faculty of Medicine, Kayseri; \\ ${ }^{2}$ Department of Anesthesia and Intensive Care, Erciyes University Faculty of Medicine, Kayseri
}

\begin{abstract}
BACKGROUND: The aim of this study was to investigate the hot milk burns among the pediatric patients and to compare our experiences with similar studies in the literature.

METHODS: A I4-year retrospective study was conducted on 159 pediatric patients with hot milk burn who hospitalized at the Burn Unit of Erciyes University Medical Faculty.

RESULTS: There were $8 \mathrm{I}$ male and 78 female patients with a male to female ratio of I.03:I. The mean age of the patients was $2.7 \pm I .6$ years. The initial injury was immersion in $59.7 \%$ of the patients and spillage in $40.3 \%$. The mean burned body surface area of the patients was $18.6 \pm 10.8 \%$. Twenty-two percent of the patients had moderate, and $78 \%$ had major burn trauma. Forty-nine percent of the patients received burn wound debridement and reconstruction with auto-skin grafts. Our burn unit's mortality rate was $1.5 \%$ among 542 pediatric patients with hot water, and $5.6 \%$ among 159 pediatric patients with hot milk burn during the same period, respectively.

CONCLUSION: Hot milk burns should be considered as separately from other hot liquid burns which do not contain fat such as water, tea, and coffee. Physical and chemical properties of milk because of its high content of fat give rise to more tissue destruction, increased morbidity and mortality.
\end{abstract}

Key words: Hot milk burn; pediatric burn; scalding.

\section{INTRODUCTION}

Burn trauma has been one of the most devastating health problems for all the times. It requires a treatment process including a multidisciplinary approach by experienced burn surgeons and health care professionals in a well-equipped burn unit or center. Majority of burns among the pediatric patients was caused by scalding in both developed ${ }^{[1,2]}$ and developing countries, ${ }^{[3,4]}$ as well as in Turkey. ${ }^{[5-7]}$ Particularly, this trauma is frequently observed among the children that belonged to

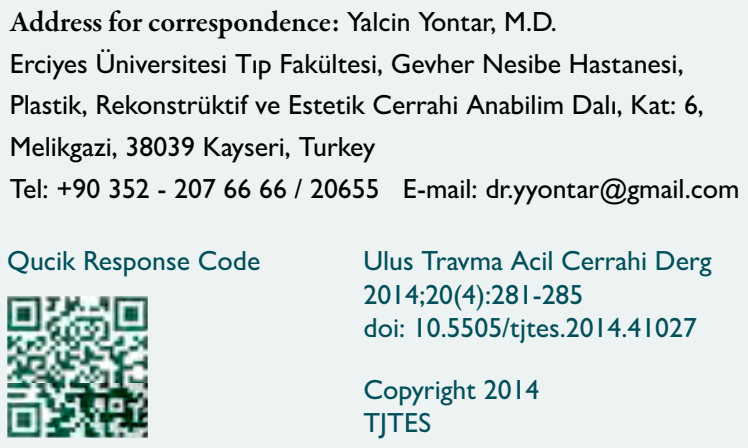

the preschool period. ${ }^{[1-7]}$ The region that our burn unit provided health care has some traditional sources of burn trauma including homemade tomato paste, jam, boiled grape juice, and dairy products such as cheese and yogurt. ${ }^{[5,8]}$ Burns due to hot milk should be considered as separately because of its physical and chemical properties. There are limited data and studies about this causative agent in the literature.

The aim of this study was to investigate hot milk burns among the pediatric aged patients and to compare our data with the literature.

\section{MATERIALS AND METHODS}

A 14-year retrospective study was conducted on 159 pediatric patients with hot milk burns who hospitalized at the Burn Unit of Erciyes University Medical Faculty between January 2000 and November 2013. According to the "American Burn Association's Grading System for Burn Severity and Disposition of Patients," the study population comprised moderate burn injuries with burned body surface area (BSA) between $5 \%$ and $10 \%$ and major burn injuries with burned BSA $>10 \%$ or any significant burn to the head and neck, genitalia or major 
joints. ${ }^{[9]}$ Outpatients with minor burns were excluded from the study group. The severity of burn injury was assessed by "abbreviated burn severity index (ABSI)" score. ${ }^{[10]}$ Initial fluid resuscitation of patients was calculated by the Parkland formula to maintain hemodynamic stability and adequate urine output. When indicated, anti-biotherapy was initiated by the pediatric infectious disease specialist and modified according to the results of antibiotic susceptibility tests. Systemic prophylactic antibiotics were not used routinely except in the perioperative period of surgical procedures. Early excision of the burn wound and closure with auto-skin grafts were applied to all deep partial and full-thickness burns. Intermingled allo- and auto-skin grafts ${ }^{[1]}$ were applied to extensive (>20\%) deep partial and full-thickness burns due to limited donor site for auto-skin graft harvesting. Wound dressing was applied with antibiotic impregnated sterile Vaseline gauze to superficial burns for primary epithelization. Collected demographic data of patients were analyzed statistically by "Statistical Package for the Social Sciences" (version 17.0.0, SPSS Inc., Chicago, IL, USA).

\section{RESULTS}

There were $8 \mathrm{I}$ male and 78 female patients with a male to female ratio of I.03:I. The age of the patients was ranged from 2 months to 10 years and the mean age was $2.7 \pm 1.6$ years. One hundred and fifty-five patients were under 6 years of age. The greatest number of injuries was observed in patients who were 2-3 years of age $(n=53)$ (Fig. I).

The majority of patients were admitted from rural regions $(n=127)$. Immersion burns were observed in $59.7 \%(n=95)$ of

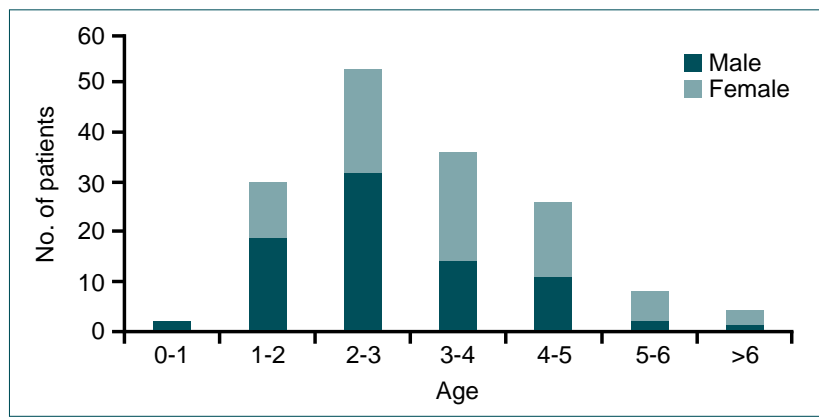

Figure 1. Patients' distribution according to age and sex.

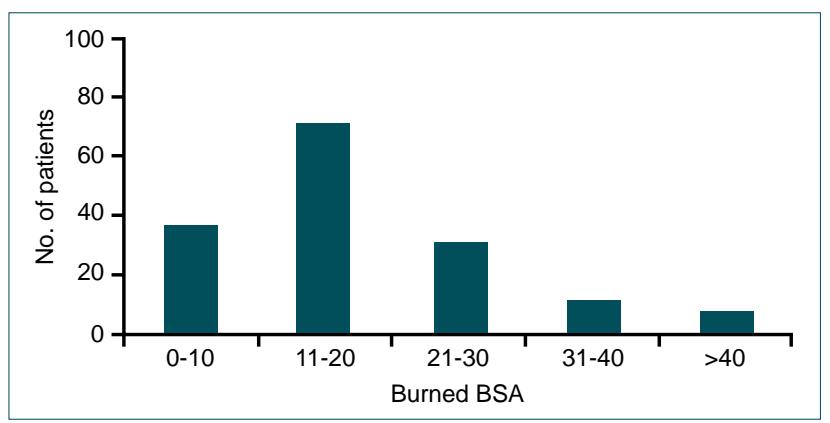

Figure 2. Patients' distribution according to burned BSA.
Table I. Affected anatomic sites of 159 patients

\begin{tabular}{lcc}
\hline Site of injury & \multicolumn{2}{c}{ No. of patients } \\
\cline { 2 - 3 } & $\mathbf{n}$ & $\%$ \\
\hline Trunk & 127 & 79.8 \\
Lower extremities & 121 & 76.1 \\
Upper extremities & 64 & 40.2 \\
Head and neck & 34 & 21.3 \\
Genito-perineal region & 7 & 4.4 \\
\hline
\end{tabular}

These numbers add to more than 159 because some patients had more than one affected area.

the patients due to mostly falling into a large cauldron made of thinned copper inside of which is tin-coated to preserve much heat. Furthermore, $40.3 \%$ of the patients $(n=64)$ were scalded by spillage. The mean burned BSA of patients was $18.6 \pm 10.8 \%$ (range, 3-54\%). Forty-four percent of the patients $(n=7 I)$ received injuries in the range of $I I-20 \%$ burned BSA. Only eight patients had burned BSA over $40 \%$ (Fig. 2). The trunk $(n=127)$ and lower extremities $(n=121)$ were affected most commonly (Table I). Twenty-two percent of the patients $(n=35)$ had moderate, and $78 \%(n=124)$ had major burn trauma. Mean ABSI score of the patients was $3.7 \pm 1.2$ (range, I-7). Five patients were epileptics, one patient had congenital

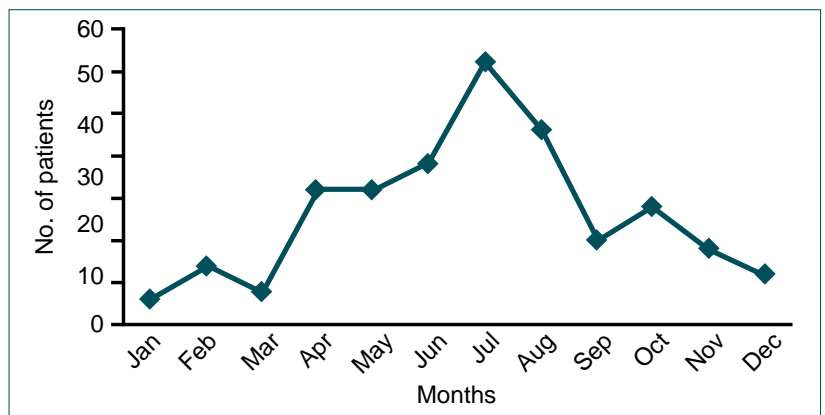

Figure 3. Monthly distribution of burn admissions.

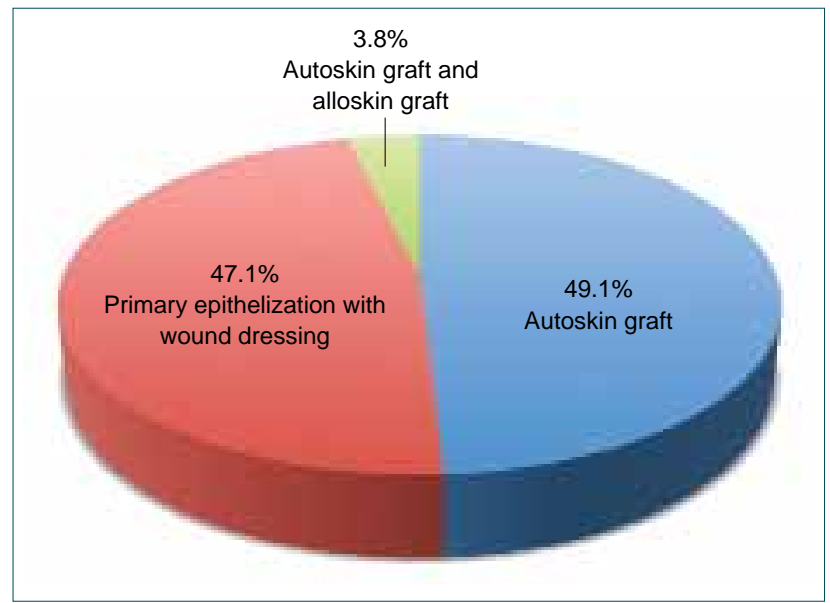

Figure 4. Patients' distribution according to applied therapy. 
Table 2. List of most important risk factors for scalding injury in children ${ }^{[1-3,5-7,17-19,22-24]}$

Being male
Preschool period
Young parents
Educational status of the parents
Living in rural areas
Low socioeconomic level
Malnutrition
Psychiatric alterations
Physical defects
Chronic illnesses
Heating of hot milk in large cauldrons
Cultural and ethnic factors
Affected body surface area
Deep dermal injury

heart disease, one patient had iron deficiency anemia, and one patient had asthma. The highest incidence of burn admissions were in July $(n=3 I)$ and August $(n=23)$ (Fig. 3).

Forty-seven percent $(n=75)$ of the patients received only burn wound dressing for primary epithelization. Forty-nine percent of the patients $(n=78)$ received burn wound debridement and reconstruction with auto-skin grafts. Intermingled allo- and auto-skin grafts were applied in 6 patients (Fig. 4).

The mean time between the injury and the surgery was $8.3 \pm 4.3$ days. Mean hospital stay was $15.4 \pm 9.8$ days. Nine patients exhibited a mortal course due to hypovolemic shock during initial fluid resuscitation period $(n=3)$ and burn wound sepsis $(n=6)$ with a mortality rate of $5.6 \%$.

\section{DISCUSSION}

Different physical and chemical properties of the hot liquids such as boiling temperature, viscosity and heat capacity play an important role regarding the degree of tissue damage. ${ }^{[12]}$
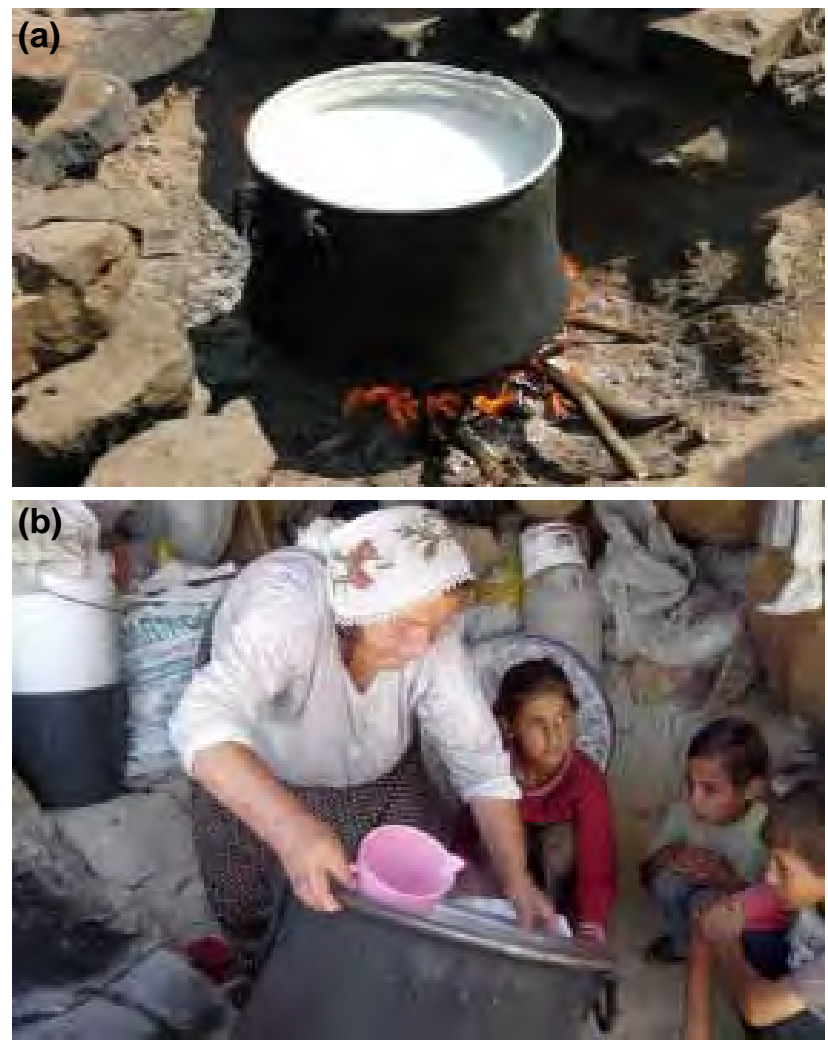

Figure 5. (a) Boiled mik in a large cauldron on wood fire, closed to the ground. (b) A cauldron that used for boiling milk is large enough to fit a preschool-aged child.

Heat is defined as the form of energy that is transferred between two systems or a system and its surroundings due to the presence of a temperature difference. The heat is always transferred from high to low temperatures until the temperature equality was established. ${ }^{[13]}$ The amount of heat required to increase the temperature of any material is given by the equation of $\mathrm{Q}=\mathrm{mC} \Delta \mathrm{T}$; where $\mathrm{Q}$ is the heat (Joule), $\Delta \mathrm{T}$ the change in temperature $\left({ }^{\circ} \mathrm{C}\right), \mathrm{m}$ the mass $(\mathrm{g})$, and $\mathrm{C}$ the heat capacity (Joule $/ \mathrm{g}^{\circ} \mathrm{C}$ ). Heat capacity is defined as the energy required to raise the temperature of unit mass of a material by ${ }^{\circ} \mathrm{C} \cdot{ }^{[14]}$ According to this equation, the tissue destruction and the severity of the burn injury with a high heat capacity liquids is worse than the lower ones, which has the same mass

Table 3. Data of patients with hot milk burn injury from different articles

\begin{tabular}{lccc}
\hline & Number of patients & Mean burned BSA (\%) & Mortality rate (\%) \\
\hline Haberal et al. ${ }^{[28]}$ & 69 & - & 61.7 \\
Tarim et al. ${ }^{[1]}$ & 45 & 33.5 & 33.3 \\
Yasti et al. ${ }^{[29]}$ & 81 & 25.3 & 32.1 \\
Türegün et al. ${ }^{[25]}$ & 15 & 25 & 20 \\
Aliosmanoglu et al. ${ }^{[17]}$ & 82 & 16.2 & 1.2 \\
Our study & 159 & 18.6 & 5.6 \\
\hline
\end{tabular}

BSA: Body surface area. 
and the temperature. The heat capacity and the boiling points of fat and fat included liquids are higher. In addition, viscosity that gained by the fat component provides prolonged contact with the surfaces. All of these factors provide more heat transmission to the tissues and thus, more tissue destruction, higher morbidity and mortality for fat and fat included liquids. Our burn unit's mortality rate of $1.5 \%$ among 542 pediatric patients with hot water burn and $5.6 \%$ among 159 pediatric patients with hot milk burn support all of these explanations.

Noted risk factors which contribute to the incidence, prevalence, morbidity, and mortality of burn injury among children are listed in Table 2. Families with a large number of children, and environmental factors are associated with the increased risk of accidental injury in childhood. ${ }^{[15]}$ In rural Kayseri, much like other rural regions of Turkey, families come from low social status and economic income. They generally produce dairy products by their own means. The first-step for the production process of dairy products involves boiling milk in a large cauldron, which is large enough to fit a preschool child, placed close to the ground in the backyard, and without a lid on a wood fire (Figs. 5a and b). In such an over-crowded family and an unsupervised environment, it is more difficult for a parent to keep track of the child's activities and to be ready and available to act for protecting them from accidental injuries. To be less able to perceive danger, have less control over their environment and to react slower in situations that can lead to injury, occasionally make the injury unavoidable in small children. ${ }^{[16]}$ As shown in our study, childhood scalding injury is frequently observed among the preschool period, especially between the ages of 2 and 3 years ${ }^{[1-3,5-7,17-19]}$ in which the abilities that increased tendency to injuries were gained such as independent mobility, exploratory behavior, and hand-to-mouth activity. ${ }^{[20,21]}$

Similar to the previous studies from Turkey ${ }^{[23,25]}$ the mechanism of hot milk burns was most commonly the immersion and most frequently affected anatomical parts were the lower extremities and the trunk. Male predominance was demonstrated in our study that in agreement with the previous studies, which had a male to female ratio ranged between 0.9:I and 2:1..$^{[15-17,25]}$ The reason for the high incidence of hot milk burns in summer season is the increased production of cheese and yogurt in this period (Fig. 3).

Fifty-one percent of our patients $(n=8 I)$ required burn wound debridement and reconstruction with auto-skin with/ without allo-skin grafts. The significant finding was that the mortality rate of the patients decreased after 2002, in which we started to perform intermingled auto- and allo-skin grafts in hot milk burns with burned BSA $>20 \%$. The mortality rate was $15.1 \%$ before 2002 and $3.1 \%$ after 2002 with an overall mortality rate of $5.6 \%$.

The practice of early burn wound excision and temporary or permanent closure of the burn wound is the standard therapy in burns, which has further reduced the mortality rate of severe burns and improves chances of survival by decreasing the stimulus of overwhelming systemic inflammatory response, preventing infectious, and metabolic complications. ${ }^{[26,27]}$

The mortality rate of hot milk burns was $61.7 \%$ in the study of Haberal et al. ${ }^{[28]}$ In their publication, there was no data of patients with hot milk burns regarding age, burned BSA, accompanying trauma, or diseases, which could explain their high mortality rate. Early excision with closure and coverage techniques that we applied to all deep partial-thickness and full-thickness burns may explain the lower mortality rate of our study compared to the previously reported mortality rates. ${ }^{[15,25,28,29]}$ Another explanation of the lower mortality rate of our study may be the lower mean burned BSA when compared to the previous studies. ${ }^{[15,25,29]}$ Furthermore, the mortality rate and mean burned BSA of patients were the lowest in the report of Aliosmanoglu et al. ${ }^{[17]}$ (Table 3).

\section{Conclusion}

Hot milk burns should be considered as separately from other hot liquid burns, which do not contain fat such as water, tea, and coffee. Physical and chemical properties of milk because of its high content of fat give rise to more tissue destruction, increased morbidity and mortality. Hence, hot milk burn patient should be evaluated initially by skilled burn surgeons for the management of hot milk burn treatment.

Conflict of interest: None declared.

\section{REFERENCES}

1. Light TD, Latenser BA, Heinle JA, Stolpen MS, Quinn KA, Ravindran $\mathrm{V}$, et al. Demographics of pediatric burns in Vellore, India. J Burn Care Res 2009;30:50-4. CrossRef

2. Abeyasundara SL, Rajan V, Lam L, Harvey JG, Holland AJ. The changing pattern of pediatric burns. J Burn Care Res 2011;32:178-84. CrossRef

3. Cuenca-Pardo J1, de Jesús Alvarez-Díaz C, Comprés-Pichardo TA. Related factors in burn children. Epidemiological study of the burn unit at the "Magdalena de las Salinas" Traumatology Hospital. J Burn Care Res 2008;29:468-74. CrossRef

4. El-Badawy A, Mabrouk AR. Epidemiology of childhood burns in the burn unit of Ain Shams University in Cairo, Egypt. Burns 1998;24:72832. CrossRef

5. Coruh A, Gunay GK, Esmaoglu A. A seven-year burn unit experience in Kayseri, Turkey: 1996 to 2002. J Burn Care Rehabil 2005;26:79-84.

6. Sakallioğlu AE, Başaran O, Tarim A, Türk E, Kut A, Haberal M. Burns in Turkish children and adolescents: nine years of experience. Burns 2007;33:46-51. CrossRef

7. Anlatici R, Ozerdem OR, Dalay C, Kesiktaş E, Acartürk S, Seydaoğlu G. A retrospective analysis of 1083 Turkish patients with serious burns. Part 2: burn care, survival and mortality. Burns 2002;28:239-43. CrossRef

8. Coruh A, Dogan F, Gunay GK. An undescribed scalding, "cökelek" burns in Turkish children: is acidic effect the reason of high mortality and double-hit injury? J Burn Care Res 2007;28:861-4. CrossRef

9. Hospital and prehospital resources for optimal care of patients with burn injury: guidelines for development and operation of burn centers. Ameri- 
can Burn Association. J Burn Care Rehabil 1990;11:98-104.

10. Tobiasen J, Hiebert JM, Edlich RF. The abbreviated burn severity index. Ann Emerg Med 1982;11:260-2. CrossRef

11. Coruh A, Tosun Z, Ozbebit U. Close relative intermingled skin allograft and autograft use in the treatment of major burns in adults and children. J Burn Care Rehabil 2005;26:471-7. CrossRef

12. Allen SR, Kagan RJ. Grease fryers: a significant danger to children. J Burn Care Rehabil 2004;25:456-60. CrossRef

13. Cengel YA, Michael AB. Energy, energy transfer, and general energy analysis. In: Thermodynamics: an engineering approach. 7th ed. New York: McGraw-Hill; 2011. p. 60.

14. Liua X, Nacsonb S, Grigorievb A, Lyndsb P, Pawliszyna J. A new thermal desorption solid-phase microextraction system for hand-held ion mobility spectrometry. Anal Chim Acta 2006;559:159-65. CrossRef

15. Tarim A, Nursal TZ, Basaran O, Yildirim S, Türk E, Moray G, et al. Scalding in Turkish children: comparison of burns caused by hot water and hot milk. Burns 2006;32:473-6. CrossRef

16. Cekin N, Akçan R, Arslan MM, Hilal A, Eren A. An unusual cause of death at preschool age: scalding by hot milk. Am J Forensic Med Pathol 2010;31:69-71. CrossRef

17. Aliosmanoglu I, Aliosmanoglu C, Gul M, Arikanoglu Z, Taskesen F, Kapan M, et al. The comparison of the effects of hot milk and hot water scald burns and factors effective for morbidity and mortality in preschool children. Eur J Trauma Emerg Surg 2013;39:173-6. CrossRef

18. Werneck GL, Reichenheim ME. Paediatric burns and associated risk factors in Rio de Janeiro, Brazil. Burns 1997;23:478-83. CrossRef

19. Henderson P, Mc Conville H, Höhlriegel N, Fraser JF, Kimble RM. Flammable liquid burns in children. Burns 2003;29:349-52. CrossRef

20. Barrow RE, Spies M, Barrow LN, Herndon DN. Influence of demo- graphics and inhalation injury on burn mortality in children. Burns 2004;30:72-7. CrossRef

21. Mytton JA, Towner EM, Kendrick D, Stewart-Brown S, Emond A, Ingram J, et al. The First-aid Advice and Safety Training (FAST) parents programme for the prevention of unintentional injuries in preschool children: a protocol. Inj Prev $2014 ; 20: e 2$.

22. Celko AM, Grivna M, Dánová J, Barss P. Severe childhood burns in the Czech Republic: risk factors and prevention. Bull World Health Organ 2009;87:374-81. CrossRef

23. Türegün $M$, Celiköz B, Nişanci M, Selmanpakoğlu N. An extraordinary cause of scalding injury in childhood. Burns 1997;23:170-3. CrossRef

24. Agran PF, Anderson C, Winn D, Trent R, Walton-Haynes L, Thayer S. Rates of pediatric injuries by 3 -month intervals for children 0 to 3 years of age. Pediatrics 2003;111:e683-92. CrossRef

25. Flavin MP, Dostaler SM, Simpson K, Brison RJ, Pickett W. Stages of development and injury patterns in the early years: a population-based analysis. BMC Public Health 2006;6:187, CrossRef

26. Alp E, Coruh A, Gunay GK, Yontar Y, Doganay M. Risk factors for nosocomial infection and mortality in burn patients: 10 years of experience at a university hospital. J Burn Care Res 2012;33:379-85. CrossRef

27. Coruh A, Yontar Y. Application of split-thickness dermal grafts in deep partial- and full-thickness burns: a new source of auto-skin grafting. J Burn Care Res 2012;33:e94-e100. CrossRef

28. Haberal M, Ugar N, Bayraktar U, Ener Z. Analysis of 1005 burn patients treated in our centre. Ann Medit. Burns Club 1993;6:73-5.

29. Yastı AÇ, Koç O, Şenel E, Kabalak AA. Hot milk burns in children: a crucial issue among 764 scaldings. Ulus Travma Acil Cerrahi Derg 2011;17:419-22. CrossRef

\section{KLINIK ÇALIŞMA - ÖZET}

\section{Yüz elli dokuz pediatrik hastada sıcak süt nedeniyle görülen yanık travmasının geriye dönük analizi: Bir yanık ünitesindeki 14 yıllık deneyim \\ Dr. Yalcin Yontar, ${ }^{1}$ Dr. Aliye Esmaoglu, ${ }^{2}$ Dr. Atilla Coruh ${ }^{1}$}

${ }^{1}$ Erciyes Üniversitesi Tıp Fakültesi, Plastik, Rekonstrüktif ve Estetik Cerrahi Anabilim Dalı, Kayseri Erciyes Üniversitesi Tıp Fakültesi, Anesteziyoloji ve Reanimasyon Anabilim Dalı, Kayseri

AMAÇ: Bu çalışmada, pediatrik hastalarda gözlenen sıcak süt yanıklarının incelenmesi ve elde edilen verilerin literatürle karşılaştırılması amaçlandı. GEREÇ VE YÖNTEM: Erciyes Üniversitesi Tıp Fakültesi Yanık Ünitesi'nde hastaneye yatırıımış I59 pediatrik hasta üzerinde I4 yıllık geriye dönük bir çalışma yapıldı.

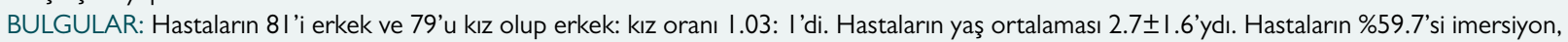
\%40.3'ü ise sütün üzerine dökülmesi/sıçraması sonucu yaralanmıştı. Hastaların ortalama yanık yüzey alanı \% | $8.6 \pm$ I0.8'di. Hastaların \%22'sinde orta derecede yanık travması varken; \%78'inde ciddi yanık travması mevcuttu. Hastaların \%49'unun tedavisi debridman ve otoderi grefti ile gerçekleştirildi. Yanık ünitemizde aynı dönem içerisinde hastaneye yatırımış 542 sıcak su yanıklı hastanın mortalite oranı \% I.5 iken, I59 sıcak süt yanıklı hastanın mortalite oranı ise \%5.6'ydı.

TARTIŞMA: Sıcak süt yanıklarının su, kahve ve çay gibi içeriğinde yağ olmayan sıcak sıvılar nedeniyle meydana gelen yanıklarından ayrı olarak değerlendirilmesi gerekmektedir. Sütün sahip olduğu yüksek yağ içeriği nedeniyle kazanmış olduğu fiziksel ve kimyasal özellikler dokularda daha fazla tahribata neden olmakta ve bu nedenle mortalite ve morbidite oranları daha fazla olmaktadır. Anahtar sözcükler: Haşlanma; pediatrik yanıklar; sıcak süt yanıkları.

Ulus Travma Acil Cerrahi Derg 20।4;20(4):28I-285 doi: 10.5505/tjtes.20।4.4I027 